\title{
Investigation of Attitudes of University Students towards Turkish Language Course and Distance Education
}

\author{
Halil Erdem Çocuk ${ }^{1}$ \\ Yunus Emre Cekici ${ }^{2}$
}

${ }^{\prime}$ Karamanoğlu Mehmetbey University, Faculty of Education, Department of Turkish Education, Turkey.

Email: halilerdemcocuk@gmail.com

${ }^{2}$ Lecturer, Adana Alparslan Türkeş Science and Technology University, Turkish Language Department, Turkey.

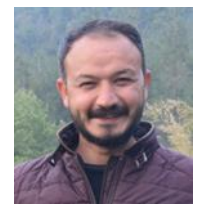

( Corresponding Author)

\section{Abstract}

Turkish language course in Turkish higher education is compulsory for all programs. Being taught for two semesters, this course has started to be given in many universities through distance education in recent years. This new situation brings about the problem as to whether there is a relationship between attitude towards distance education and attitude towards Turkish language lesson. It was aimed in this study to examine and compare the attitudes of university students who take Turkish Language courses through distance education towards this course and distance education system in terms of various variables. In this descriptive research, a survey model was used to obtain data. The study group consists of the 181 freshmen attending a state university located in the south of Turkey and taking Turkish language lessons in the 2018-2019 academic year. Data were collected with attitude scales whose validity and reliability was tested. Difference tests between means were performed in data analysis. It was concluded in the study that the attitude of undergraduate freshman students towards Turkish Language course and distance education is above average, but not very high. It can also be foreseen according to findings of this study that university students' attitudes towards Turkish language course will improve as their attitudes towards distance education increase.

Keywords: Distance education, Turkish language course, Language education, Turkish higher education, University students, Attitude.

Citation | Halil Erdem Çocuk; Yunus Emre Çekici (2020). Investigation of Attitudes of University Students towards Turkish Language Course and Distance Education. Asian Journal of Education and Training, 6(2): 261-266.

History:

Received: 23 January 2020

Revised: 5 March 2020

Accepted: 8 April 2020

Published: 11 May 2020

Licensed: This work is licensed under a Creative Commons

Attribution 3.0 License $(\mathrm{cc})$ Er

Publisher: Asian Online Journal Publishing Group
Acknowledgement: Both authors contributed to the conception and design of the study.

Funding: This study received no specific financial support

Competing Interests: The authors declare that they have no conflict of interests.

Transparency: The authors confirm that the manuscript is an honest, accurate, and transparent account of the study was reported; that no vital features of the study have been omitted; and that any discrepancies from the study as planned have been explained.

Ethical: This study follows all ethical practices during writing.

\section{Contents}

1. Introduction

References. 


\section{Contribution of this paper to the literature}

This study contributes to the existing literature by examining and comparing the attitudes of university students who take Turkish courses through distance education towards this course and the distance education system. The study group, in the south of Turkey and Turkish courses in the 2018-2019 academic year, first-year students attending a state university is composed. All students taking Turkish lessons in this university participated in the research.

\section{Introduction}

Formal mother tongue education, which starts in the pre-school period in Turkey, is carried out with the courses "Turkish" in primary and secondary school and "Turkish Language and Literature" in high school. There are also many elective courses in secondary and high schools aimed at improving students' comprehension and narrative skills in their mother tongue. Mother tongue education, the main purpose of which is to develop comprehension (reading and listening) and narrative (speaking and writing) skills (Adalı, 1983; Göçer, 2015; Lüle, 2014; Ozdemir, 1983) is stated as a requirement not only in the compulsory education period, but also at the university level. The fact that the students who start university do not have enough proficiency in Turkish, have difficulty in understanding what they read and listen, and not being able to effectively express their thoughts both verbally and in writing brought up the idea of giving mother tongue education in universities (Adall, 1983; Cemiloğlu, 2004; Durukan, 2017; Yekbaş, 2011). Turkish Language course has been given in this context. The Turkish language lessons began to be taught in Hacettepe University in 1968, in Ege University in 1977, and later in all universities in Turkey followed by the establishment of the Higher Education Council in 1981 (Cotuksöken, 2014). Within the scope of the 5/i sub-article of the Higher Education Law (1981) it is compulsory to give Turkish Language course in higher education institutions. This course is taught as Turkish Language I and Turkish Language II in the first grades of associate and undergraduate programs, for a total of 28 weeks in two semesters. Due to the decrease in space cost and student expenses, flexibility in following the lesson, and the use of audio and visual elements (Tulunay, 2014) Turkish language lessons are given by distance education system in many universities. However, this situation brings about new problems, especially in terms of attitude towards the lesson.

Inability of the student to realize the importance of the course (Bakır, 2010) indifference (Vural, 2007) insensitivity about language awareness and education (Yekbaş, 2011) ignoring this course alongside field courses, perceiving it as a negligible course (Cemiloğlu, 2004) is among the problems encountered during the delivery of Turkish Language courses. The quality of the attitude towards the course underlies these problems. "Failure to achieve the purpose of Turkish Language course which is compulsory to be taught in colleges and faculties in Turkey in two semesters is due to the negative attitudes such as students' being indifferent to this course, their disbelief in importance of the course and lack of motivation" (Alan \& Bağcl, 2016). As, in recent years, Turkish Language lessons have been carried out with distance education system in many universities, the attitude towards distance education system is to be considered as an important requirement.

Attitude is a positive or negative emotion towards a physical object, a certain type of community or person, government or social institution's policy or thought (Atar, 2016). Kaplan (2018) on the other hand, stated that attitude is an intrinsic response or behavioral tendency that occurs as a result of previous experiences and leads the next experiences. Each attitude has two aspects as positive and negative. The person can have a positive or negative tendency towards any subject, event, situation, etc. If this tendency is positive, the person develops a positive attitude towards the subject, event and situation; if negative, the attitude developed by the person is also negative (Temizkan \& Sallabaş, 2009). Therefore, attitude directly affects learning. The teaching of the Turkish language in universities is a subject of longstanding discussion. Recently, these courses have been discussed to be given by distance education and many universities have already started it. The attitude towards both the teaching of Turkish language and distance education will also determine the quality of learning.

When the literature is examined, it is seen that the studies on the Turkish Language course are quite limited. In the literature, there are studies addressing the students' opinions about Turkish Language lessons (Gülay \& Durukan, 2012) students' attitudes towards Turkish Language lessons (Alan \& Bağcl, 2016; Durukan, 2017) attitudes of students who take Turkish Language course towards Turkish (Karataş, 2013) the problems that reduce the effectiveness of Turkish language course and suggestions to these problems (Gülay \& Ungan, 2015) the contribution of the Turkish language course to the affective development of students (Sarıtunç, 2016) and the comparison of undergraduate and graduate students' success in Turkish Language (Korkmaz, Kalkan, Doğan, Doğruluk, \& Aydın, 2018). In addition, there are also studies aiming to determine the views of students on the Turkish Language lessons conducted by distance education (Kan \& Fidan, 2016; Kırbaş, 2017) as well as the views of both students and lecturers (Arslan, 2018). Researches on developing an attitude scale towards Turkish language lesson (Akkaya \& Sevindi, 2015; Arslan, 2012) were also conducted. However, there is no study comparing students' attitudes towards distance education with their attitudes towards Turkish language lesson.

The aim of this study is to examine and compare the attitudes of university students who take Turkish Language courses through distance education towards this course and distance education system. It is thought that this study will contribute to the Turkish Language lessons conducted with the distance education system, especially in the preparation of the course content and determining method. In this context, the answer to the following questions will be sought in the study.

1. What degree is the attitude of university students who take Turkish Language courses through distance education towards this course?

2. Is there any difference in the attitudes of university students taking Turkish Language courses through distance education towards this course by gender and faculty variables?

3. What degree are the distance education attitudes of university students who take Turkish Language courses through distance education?

4. Is there a difference in the distance education attitudes of university students who take Turkish Language courses through distance education by gender and faculty variables? 
5. Is there a significant relationship between the attitudes of university students taking Turkish Language courses through distance education towards this course and their attitudes towards distance education?

\section{Method}

In this section, the research model, the information about the study group, the data collection and the analysis process of the data are discussed.

\subsection{Research Model}

This study is a descriptive research to examine the attitudes of university students taking Turkish Language courses through distance education towards this course and the distance education system. Survey model was used to obtain the data. Survey models are a research approach that aims to describe a past or present situation as it is. The event, individual or object, as the subject of the research, is to be defined within its own conditions and as it is (Karasar, 2008).

\subsection{Study Group}

The study group consists of the freshmen attending a state university located in the south of Turkey and taking Turkish language lessons in the 2018-2019 academic year. All students taking Turkish Language course in this university participated in the research. Table 1 shows the information about study group.

Table-1. Information about study group.

\begin{tabular}{l|l|c|c}
\hline \multicolumn{2}{c}{ Table-1. Information about study group. } \\
\hline \multirow{2}{*}{ Gender } & Male & Frequency & Percentage (\%) \\
\cline { 2 - 4 } & Female & 112 & 61,9 \\
\hline \multirow{2}{*}{ Faculty } & Engineering & 69 & 38,1 \\
\cline { 2 - 4 } & Business Administration & 122 & 67,4 \\
\cline { 2 - 4 } & Humanities and Social Sciences & 32 & 17,7 \\
\hline
\end{tabular}

\subsection{Data Collection Tools}

The data of this study were obtained through "Attitude Scale Towards Turkish Language Course in Higher Education" developed by Arslan (2012) and "Distance Education Attitude Scale" developed by Arslan (2012).

The "Distance Education Attitude Scale" developed by Arslan (2012) was applied to 200 teachers working in 6 primary schools in Balıkesir and having knowledge about distance education. Reliability and validity of the scale were calculated by making item analysis and factor analysis, and as a result of the calculation, the scale was composed of 21 items. 14 of the items are positive and 7 of them are negative. According to the analyzes, the scale was found to consist of 6 factors. The Kaiser-Meyer-Olkin (KMO) coefficient of the scale was 0.814, the Barlett Test significance value was 0.000 , and the Cronbach-alpha reliability coefficient was 0.835. In this study, Cronbach Alpha internal consistency coefficient was calculated as 0.854.

The "Attitude Scale Towards Turkish Language Course in Higher Education" developed by Arslan (2012) was applied to a total of 331 university students who took Turkish Language lessons. In the study, seven different statistical analyzes (Cronbach Alpha coefficient, KaiserMeyerOlkin, Barlett's Test of Sphericity analysis, Scree Plot graph, Factor analysis, Correlation analysis, t test) were performed. As a result of the analyzes, it was revealed that the item-total score correlations of all items of the scale were found to be significant at $\mathrm{p}<0.01$ significance level, the Cronbach Alpha coefficient of the scale was 0.96 and the factor load of all items was above 0.60, and all " $\mathrm{t}$ " values related to the distinctiveness of the scale were significant. In this study, Cronbach Alpha internal consistency coefficient was calculated as 0.92 .

\subsection{Data Analysis}

Difference tests between the means were conducted in order to determine whether the attitudes of university students taking Turkish Language courses through distance education towards this course and the distance education system differ according to the variables. For this purpose, it was firstly examined whether the dependent variable is normally distributed according to the independent variable. Since the number of participants of the study group was 181, Kolmogrov-Simirnov, one of the normality tests, was examined. As a result of the normality test $(p>0.05)$ of university students taking Turkish Language courses through distance education, the data were seen to show a normally distribution. For this reason, as parametric statistics, Independent Samples $\mathrm{T}$ test and One-Factor Variance Analysis (One-Way Anova) were used for data analysis. Pearson correlation analysis was performed in the relationship between the scales.

\section{Findings}

In this section, the findings obtained from the analysis of problem statements are given. In the first problem sentence of the study, the attitude scores of university students taking Turkish Language courses through distance education were investigated. The data analysis results are presented in Table 2.

Table-2. Distribution of Turkish language attitude scores.

\begin{tabular}{l|c|c|c|c|c|c}
\hline Scale & Study Group & Minimum & Maximum & Mean & Standard Deviation \\
\hline $\begin{array}{l}\text { Attitude Scale Towards Turkish } \\
\text { Language Course in Higher Education }\end{array}$ & 181 & 41,00 & 133,00 & 95,35 & 21,06 \\
\hline
\end{tabular}

When Table 2 is examined, it is seen that the minimum value of the Turkish language attitude scores of the students participating in the research is 41 and the highest value is 133 while the mean score is 95 . It was determined that the lowest score that can be obtained from this scale is 29 and the highest score is 145. 
Accordingly, it was stated that the attitudes of students with a total score of 58 and below can be evaluated as negative (Arslan, 2012). In this context, though quite above the average, the attitudes of the students participating in the research towards the Turkish language cannot said to be high.

In the second problem statement, it was investigated whether there is a difference in the attitudes of university students taking Turkish Language courses through distance education towards this course in terms of gender and faculty variables. Findings related to gender are shown in Table 3.

\begin{tabular}{c|c|c|c|c|c|c}
\multicolumn{8}{c}{ Table-3. T-test results of Turkish language attitude scores by gender. } \\
\hline Gender & $\mathbf{N}$ & $\mathbf{X}$ & $\mathbf{S}$ & $\mathbf{d f}$ & $\mathbf{t}$ & $\mathbf{p}$ \\
\hline Male & 112 & 94,36 & 22,30 & & & \multirow{2}{*}{, 421} \\
\hline Female & 69 & 96,97 & 18,92 & 179 & 0,87 &, 421 \\
\hline
\end{tabular}

As a result of the independent samples $t$ test to determine whether the attitudes of university students taking Turkish Language courses through distance education towards this course differ by gender, it was found that there is no significant difference $\left(\mathrm{t}_{(179)}=0.87, \mathrm{p}>.005\right)$. Accordingly, it can be said that gender is not a factor affecting the attitudes of university students taking Turkish Language courses through distance education towards this course.

Another item of this problem statement is whether Turkish language attitude scores differ according to faculty variable. The one-way ANOVA results for this are shown in Table 4.

Table-4. Anova results of the attitude scale towards Turkish language course in higher education by faculty.

\begin{tabular}{|c|c|c|c|c|c|}
\hline Grade & Freque & & Mean & \multicolumn{2}{|c|}{ Standard Deviation } \\
\hline 1,00 & 122 & & 93,42 & \multicolumn{2}{|c|}{21,98} \\
\hline 2,00 & 32 & & 95,68 & \multicolumn{2}{|c|}{21,09} \\
\hline $4, \mathrm{OO}$ & 27 & & 103,70 & \multicolumn{2}{|c|}{14,26} \\
\hline Total & 181 & & 93,42 & \multicolumn{2}{|c|}{21,98} \\
\hline Source of Variance & Sum of Squares & df & Mean Squares & $\bar{F}$ & $\overline{\mathbf{P}}$ \\
\hline Between groups & 2339,317 & 2 & 1169,658 & \multirow{3}{*}{2,685} & \multirow{3}{*}{, 102} \\
\hline Within groups & 77552,341 & 178 & 435,687 & & \\
\hline Total & 79891,657 & 180 & & & \\
\hline
\end{tabular}

As a result of one way ANOVA to determine whether the attitudes of university students taking Turkish Language courses through distance education towards this course by faculty, it was found that there is no significant difference $\left(\mathrm{F}_{(178)}=2.685, \mathrm{p}>.005\right)$. In other words, it can be said that faculty is not a factor affecting the attitudes of university students taking Turkish Language courses through distance education towards this course.

In the other problem sentence of the study, the distance education attitude scores of university students who took Turkish Language courses through distance education were investigated. The data analysis results obtained are presented in Table 5 .

Table-5. Distribution of distance education attitude scores.

\begin{tabular}{c|c|c|c|c|c}
\hline Scale & Study Group & Minimum & Maximum & Mean & Standard Deviation \\
\hline Distance Education Attitude Scale & 181 & 29,00 & 98,00 & 68,74 & 13,76 \\
\hline
\end{tabular}

When Table 5 is examined, it is seen that the minimum value of the distance education attitude scores of the students participating in the research is 29 and the highest value is 98 while the mean score is 68.78 . It was determined that the lowest score that can be obtained from this scale is 21 and the highest score is 105 . Accordingly, it was stated that the attitudes of students with a total score of 42 and below can be evaluated as negative (Agır, Gür, \& Okçu, 2007). Accordingly, students' attitudes towards distance education are above average. It can be said that, although it is not very high as attitude scores towards Turkish language, it shows a positive attitude towards distance education.

In the fourth problem statement, it was examined whether there is a difference in the distance education attitudes of university students taking Turkish Language courses through distance education in terms of gender and faculty variables. Findings related to gender are shown in Table 6.

\begin{tabular}{c|c|c|c|c|c|c}
\multicolumn{7}{c}{ Table-6. T-test results of distance education attitude scores by gender. } \\
\hline Gender & $\mathbf{N}$ & $\mathbf{X}$ & $\mathbf{S}$ & $\mathbf{d f}$ & $\mathbf{t}$ & $\mathbf{p}$ \\
\hline Male & 112 & 70,47 & 14,09 & & & \\
\hline Female & 69 & 65,94 & 12,80 & 179 & 2,17 &, 031 \\
\hline
\end{tabular}

As a result of the independent samples $t$ test to determine whether the distance education attitudes of university students taking Turkish Language courses through distance education differ by gender, a significant difference was found $\left(t_{(179)}=2.17, \mathrm{p}>\right.$.005). Accordingly, the mean score of male students is significantly higher than that of female students, and their attitude towards distance education is more positive.

Another item of fourth problem statement is whether distance education attitude scores differ according to faculty variable. The one-way ANOVA results for this are shown in Table 7.

Table-7. Anova results of the distance education attitude scale by faculty.

\begin{tabular}{c|c|c|c}
\hline Grade & Frequency & Mean & Standard Deviation \\
\hline 1,00 & 122 & 69,85 & 13,30 \\
\hline 2,00 & 32 & 69,75 & 14,76 \\
\hline 4,00 & 27 & 62,55 & 13,42 \\
\hline Total & 181 & 68,74 & 13,76 \\
\hline
\end{tabular}




\begin{tabular}{c|c|c|c|c|c|c}
\hline Source of Variance & Sum of Squares & df & Mean Squares & F & p & Significant difference \\
\hline Between groups & 1216,298 & 2 & 608,149 & & & \\
\cline { 1 - 4 } Within groups & 32866,011 & 178 & 184,641 & \multirow{2}{*}{3,294} & \multirow{2}{*}{, 039} & \\
\hline Total & 34082,309 & 180 & & & & \\
\hline
\end{tabular}

As a result of one way ANOVA to determine whether the distance education attitudes of university students taking Turkish Language courses through distance education by faculty, a significant difference was found $(\mathrm{F}(178)=3.294, \mathrm{p}<.005)$. Attitude scores of Engineering Faculty towards distance education are significantly higher than that of Faculty of Humanities and Social Sciences, and their attitude towards distance education is more positive.

In the fifth problem statement, a significant relationship between the attitudes of university students taking Turkish Language courses through distance education towards this course and distance education was tested by Pearson correlation analysis. The findings are shown in Table 8.

Table-8. Relationship between Turkish language attitudes and distance education attitudes.

\begin{tabular}{l|l|c|c}
\hline \multicolumn{2}{l}{ Turkish language attitudes } & Turkish language attitudes & Distance education attitudes \\
\cline { 2 - 4 } & Pearson Correlation & 1 &, $369^{* *}$ \\
\cline { 2 - 4 } & Sig. (2-tailed) & &, 000 \\
\cline { 2 - 4 } & $\mathrm{N}$ & 181 & 181 \\
\hline \multirow{2}{*}{ Distance education attitudes } & Pearson Correlation &, $369^{* *}$ & 1 \\
\cline { 2 - 4 } & Sig. (2-tailed) &, 000 & 181 \\
\cline { 2 - 4 } & $\mathrm{N}$ & 181 & 18 \\
\hline
\end{tabular}

As a result of the Pearson correlation analysis to determine the relationship between the attitudes of university students taking Turkish Language courses through distance education towards this course and distance education, a significant relationship was revealed $(\mathrm{r}=.369 ; \mathrm{p}<.01)$. Accordingly, it can be said that, as the attitudes of university students towards distance education increase, their attitudes towards Turkish language will also improve.

\section{Conclusion, Discussion and Suggestions}

The results of this study, which aims to examine and compare the attitudes of university students taking Turkish Language courses through distance education towards this course and distance education system, are given below.

The attitudes of undergraduate freshman students towards Turkish language course are above average, but not very high. However, gender and faculty variable are not among the factors affecting the attitude towards Turkish Language course. Although the distance education attitude of undergraduate freshman students is above average, it is not very high. Male students' attitude towards distance education is more positive than female students. Moreover, the attitude of the students in Faculty of Engineering towards distance education is more positive than those in Faculty of Humanities and Social Sciences. It is another result of this study that the attitude of university students towards Turkish language course will increase as their attitudes towards distance education improve.

In this study, it was concluded that undergraduate freshman students' attitude towards Turkish Language course is above average but not very high. A similar result was found in Alan and Bağcı (2016) research, which revealed that the attitudes of the freshman students in the faculties and schools of Mehmet Akif Ersoy University towards Turkish Language I-II course are at a medium level.

In this study, it was concluded that gender and faculty factor are not among the variables that affect the attitude towards the Turkish Language course. However, in the study by Durukan (2017) it was found that the attitudes of female students towards Turkish Language lesson were more positive than male students.

It was also concluded in this study that undergraduate freshman students' attitude towards distance education is above average but not very high. The reasons for the result that students' attitude towards distance education is above average can be due to the application of distance education at any time and place (Croft, Dalton, \& Grant, 2010; Lake, 1999; Subic \& Maconachie, 2004) suitability for the individual progress of students (Croft et al., 2010) decrease in student expenses, flexibility to follow the course and enrichment of the course with audiovisual elements (Tulunay, 2014).

The male students' attitude towards distance education was found to be more positive than women in this study. While this result is parallel to some research in the literature (Fidan, 2016) it does not match with some research (Ates \& Altun, 2008).

In his study at Ağrı İbrahim Çeçen University, Arslan (2018) reached the conclusion that faculty members and students did not agree to conduct the Turkish language course through distance education. On the other hand, Kan and Fidan (2016) revealed that the students at the University of Erciyes agreed that the Turkish Language lessons through distance education were positive allowing them to watch again from the archive, while they adressed the lack of practice and communication as a problem. It can be foreseen according to our study that university students' attitudes towards Turkish language course will also increase if their attitudes towards distance education increase.

It is observed that distance education has become widespread in recent years in Turkish higher education (Akdemir, 2011; Bozkurt, 2017; Yaman, 2015). Therefore, improvement in distance education will enable students to develop a positive attitude towards the lessons and, in this way, the quality of higher education will improve. Today, both the distance education system should be improved and the instructors giving the course must have effective teaching methods with this system in order to increase the efficiency of Turkish Language courses, which are mostly carried out through distance education. 


\section{References}

Adal, O. (1983). Teaching Turkish: On teaching Turkish as a mother tongue. Turkish Language Journal of Language and Literature, 47(379), 31-35.

Agır, F., Gür, H., \& Okçu, A. (2007). Development of the attitude scale toward distance learning: Reability and validity. e-Journal of Nerw World Sciences Academy, 3(2), 128-139.

Akdemir, Ö. (2011). Distance education in our higher education. Journal of Higher Education and Science, 1(2), 69-71.Available at: http://doi.org/10.5961/jhes.2011.011.

Akkaya, N., \& Sevindi, Z. E. (2015). Developing attitude scale towards common compulsory Turkish Language courses taught at universities. Buca Education Faculty Journal, 35, 92-103.

Alan, N., \& Bağcı, H. (2016). Evaluation of attitudes of university students towards Turkish language I-II course. Mehmet Akif Ersoy University Journal of Education Faculty, 38, 118-132.

Arslan, A. (2012). Validity and reliability study of attitude scale towards Turkish language course in higher education. International Turkish Literature Culture Education Journal, 1(3), 187-202.

Arslan, A. (2018). Evaluation of the opinions of the lecturer and student about the teaching of Turkish language by distance education (A $\breve{g} r$ İbrahim Çeçen University Sample). Paper presented at the International Culture and Science Congress 3-4-5 May 2018 Full Text Book.

Atar, H. Y. (2016). School ability, career interest, attitudes and personality tests. Bayram Bıçak, Mustafa Bahar and Serkan Özel (Ed.), In the Educational Evaluation of Students (pp. 414-435). Ankara: Nobel.

Ates, A., \& Altun, E. (2008). Examining the attitudes of computer teacher candidates towards distance education in terms of various variables. Gazi University Journal of Gazi Education Faculty, 28(3), 125-145.

Bakır, S. (2010). An evaluation of midwife and nurse candidates' written expression skills in Turkish Language course (Atatürk University Faculty of Health Sciences Sample). Unpublished Master's Thesis, Atatürk University Institute of Social Sciences.

Bozkurt, A. (2017). The distance education in Turkey yesterday, today and tomorrow. Journal of Open Education Practices and Researches, 3(2), 85-124.

Cemiloğlu, M. (2004). Evaluations, evaluations and suggestions about Turkish Language course taught at universities. Uludă̆ University Journal of Education Faculty, $17(2), 173-182$.

Cotuksöken, Y. (2014). Applied Turkish language. Istanbul: Papatya Publishing.

Croft, N., Dalton, A., \& Grant, M. (2010). Overcoming isolation in distance learning: Building a learning community through time and space. Journal for Education in the Built Environment, 5(1), 27-64.Available at: https://doi.org/10.11120/jebe.2010.05010027.

Durukan, Ş. (2017). Investigation of the attitudes of school of physical education and sports students towards Turkish language course in terms of demographic variables. MCBÜ Journal of Social Sciences, 15(1), 289-306.

Fidan, M. (2016). Distance education students' attitudes towards distance education and their epistemological beliefs. Hacettepe University Faculty of Education Journal, 31(3), 536-550.

Göçer, A. (2015). The place, function and teaching of the grammar learning area in the development of basic language skills: A thematic approach in the axis of integrity and induction method. Journal of Education and Training Researches, 4(1), 233-242.

Gülay, E., \& Durukan, E. (2012). Examining the views of vocational school students about the Turkish language course: An action research. International Turkish Literature Culture Education Journal, 1(2), 38-50.

Gülay, E., \& Ungan, S. (2015). An action research aiming at investigating the content and classroom ambient in Turkish language course in terms of effectiveness of Turkish language course. International Journal of Language Academy, 3(1), 337-360.

Higher Education Law. (1981). T. C. Official Gazette, 2547, 4 December 1981.

Kan, A. Ü., \& Fidan, E. K. (2016). Students' perceptions about conducting the Turkish language course with distance education. Turkish Journal of Educational Studies, 3(2), 23-45.

Kaplan, T. (2018). The effect of authentic writing studies in teaching Turkish to foreigners on students' writing skills and attitudes. Ph.D. Thesis, Department of Turkish and Social Sciences Education, Department of Turkish Education. Sakarya.

Karasar, N. (2008). Research methods (18th ed.). Ankara: Nobel Publishing.

Karataş, M. (2013). Turkish language course and attitudes about Turkish at universities. Turkish Studies, 8(1), $1881-1898$.

Kırbaş, A. (2017). Attitudes of students taking Turkish Language course with distance education program in higher education (Gümüşhane University sample). International Journal of Language Academy, 5(8), 449-457.

Korkmaz, M., Kalkan, N., Doğan, A., Doğruluk, M., \& Aydın, C. C. (2018). Comparison of success rates of Turkish language courses taught by distance education method at Hacettepe University in associate and undergraduate programs. $M B D, 7(2), 207-215$.

Lake, D. (1999). Reducing isolation for distance students: An on-line initiative. Open Learning: The Journal of Open, Distance and e-Learning, 14(3), 14-23.Available at: https://doi.org/10.1080/0268051990140304.

Lüle, M. E. (2014). Examples of activities that can be used in the development of four basic language skills in the education and training of Turkish. Journal of Mother Tongue Education, 2(1), 23-48.

Ozdemir, E. (1983). Mother tongue teaching. Turkish Language Journal of Language and Literature, 18-30.

Saritunç, B. (2016). Contribution of Turkish Language lessons to the affective development of students in higher education. Karaelmas Journal of Educational Sciences, 4, 50-58.

Subic, A., \& Maconachie, D. (2004). Flexible learning technologies and distance education: A teaching and learning perspective. European Journal of Engineering Education, 29(1), 27-40.Available at: https://doi.org/10.1080/0304379032000129322.

Temizkan, M., \& Sallabaş, E. (2009). Comparison of pre-service teachers' attitudes towards reading and writing. Electronic Journal of Social Sciences, 8(27), 155-176.

Tulunay, A. O. (2014). Evaluation of distance education in higher education with numerical data. Bayburt University Faculty of Education Journal, 9(1), 22-40.

Vural, H. (2007). On the Turkish language course taught at universities. Turkish Language Journal of Language and Literature, 94(669), 496503.

Yaman, İ. (2015). Pros and cons of providing compulsory English (51) courses through distance education at universities. Turkish Studies, 1O(7), 967-984.Available at: http://dx.doi.org/10.7827/turkishstudies.8108.

Yekbaş, H. (2011). Some determinations and solution suggestions related to Turkish Language course taught at universities. Paper presented at the III. International World Language Turkish Symposium Proceedings Book. 